\title{
Overlooked Diversity of Ultramicrobacterial Minorities at the Air-Sea Interface
}

\author{
Janina Rahlff ${ }^{1,2, *}$, , Helge-Ansgar Giebel ${ }^{3}$, Christian Stolle ${ }^{1,4,5}$, Oliver Wurl ${ }^{1}{ }^{\circledR}$, \\ Alexander J. Probst ${ }^{2}$ and Daniel P. R. Herlemann ${ }^{6}$ \\ 1 Center for Marine Sensors, Institute for Chemistry and Biology of the Marine Environment (ICBM), \\ Carl von Ossietzky University Oldenburg, 26382 Wilhelmshaven, Germany; christian.stolle2@uol.de (C.S.); \\ oliver.wurl@uol.de (O.W.) \\ 2 Group for Aquatic Microbial Ecology, Environmental Microbiology and Biotechnology, Department of \\ Chemistry, University of Duisburg-Essen, 45141 Essen, Germany; alexander.probst@uni-due.de \\ 3 Institute for Chemistry and Biology of the Marine Environment (ICBM), \\ Carl von Ossietzky University Oldenburg, 26111 Oldenburg, Germany; giebel@icbm.de \\ 4 Leibniz Institute for Baltic Sea Research (IOW), Seestraße 15, 18119 Rostock, Germany \\ 5 Project management Jülich, Schweriner Str. 44, 18069 Rostock, Germany \\ 6 Chair of Hydrobiology and Fishery, Institute of Agricultural and Environmental Sciences, \\ Estonian University of Life Sciences, Kreutzwaldi 5, Tartu 51006, Estonia; daniel.herlemann@emu.ee \\ * Correspondence: janina.rahlff@uol.de
}

Received: 14 September 2020; Accepted: 6 November 2020; Published: 10 November 2020

\begin{abstract}
Members of the Candidate phylum Patescibacteria, also called Candidate Phyla Radiation (CPR), are described as ultramicrobacteria with limited metabolic capacities. Wide diversity and relative abundances up to $80 \%$ in anaerobic habitats, e.g., in groundwater or sediments are characteristic for Candidatus Patescibacteria. However, only few studies exist for marine surface water. Here, we report the presence of 40 patescibacterial candidate clades at air-sea interfaces, including the upper water layer, floating foams and the sea-surface microlayer (SML), a $<1 \mathrm{~mm}$ layer at the boundary between ocean and atmosphere. Particle-associated $(>3 \mu \mathrm{m})$ and free-living (3-0.2 $\mu \mathrm{m}$ ) samples were obtained from the Jade Bay, North Sea, and 16S rRNA (gene) amplicons were analyzed. Although the abundance of Cand. Patescibacteria representatives were relatively low $(<1.3 \%)$, members of Cand. Kaiserbacteria and Cand. Gracilibacteria were found in all samples. This suggests profound aerotolerant capacities of these phylogenetic lineages at the air-sea interface. The presence of ultramicrobacteria in the $>3 \mu \mathrm{m}$ fraction implies adhesion to bigger aggregates, potentially in anoxic niches, and a symbiotic lifestyle. Due to their small sizes, Cand. Patescibacteria likely become aerosolized to the atmosphere and dispersed to land with possible implications for affecting microbial communities and associated processes in these ecosystems.
\end{abstract}

Keywords: Candidate phyla radiation; bacteria; sea-surface microlayer; neuston; foam; 16S rRNA sequencing; aerosols; air-sea interface

\section{Introduction}

Ultra-small bacteria of the Candidate Phylum Patescibacteria [1] also called Candidate Phyla Radiation (CPR) comprise a high biodiversity within the bacterial domain [2,3]. Cand. Patescibacteria include Microgenomates (OP11), Parcubacteria (OD1), Dojkabacteria (WS6), Katanobacteria (WWE3), Gracilibacteria, Berkelbacteria (ACD58), Peregrinibacteria (PER), Kazania, ABY1, CPR2, and Saccharibacteria (TM7) [4]. Due to reduced cell and genome sizes only limited metabolic capacities are hitherto described for these bacteria [5]. Therefore, Cand. Patescibacteria have been suggested to be symbionts of other microbes [6-9] or even considered virus-like [10]. Because of the frequent lack of 
a respiratory chain $[5,10]$ and their presence in oxygen-deprived and anaerobic ecosystems [11-14] a fermentative-based lifestyle has been suggested for most Cand. Patescibacteria [10]. However, Cand. Patescibacteria were also detected in oceans at a depth of $5 \mathrm{~m} \mathrm{[15],} \mathrm{aerobic} \mathrm{surface} \mathrm{water} \mathrm{of} \mathrm{a}$ thermokarst lake ecosystem [16], deep oxic Lake Baikal [17], and oxic mixolimnion of Lake Parvin [18]. For their oxic lifestyle an unusual respiratory metabolism especially of Cand. Parcubacteria has been proposed $[19,20]$. In addition, recent work suggested that nano-sized prokaryotes including Cand. Patescibacteria could contribute to carbon cycling in the oceans [21] and supported by a high diversity of Cand. Patescibacteria, important implications for exchange processes across the air-sea boundary can be inferred [22].

Microorganisms populating the sea-surface microlayer (SML), a $<1 \mathrm{~mm}$ layer at the air-sea boundary, are collectively referred to as neuston and encompass cell numbers of $2 \times 10^{23}$ on Earth [23]. The biofilm-like, gelatinous nature of the SML [24] with its distinct physicochemical features compared to the underlying water (reviewed by Cunliffe, et al. [25]) and spontaneously emerging surface phenomena, such as slicks and foams found increasing research interest as bacterial habitats during the last decade [24,26-29]. However, very little is known about the role of ultramicrobacteria in this elusive ecotone between atmosphere and hydrosphere. In recent studies, Cand. Patescibacteria were detected in freshwater SML in Lake Parvin, France with slight enrichments over the epilimnion [30]. Furthermore, Cand. Patescibacteria were present in air samples collected over the Southern Ocean [31], but their origin remained unclear.

In this study, we hypothesize that also saltwater bacterial communities in $1 \mathrm{~m}$ deep water, the SML, and foam harbor ultramicrobacteria of the phylum Cand. Patescibacteria, and that these are potential components of aerosols. We differentiate the $0.2-3 \mu \mathrm{m}$ ("free-living") and the $>3 \mu \mathrm{m}$ fraction ("particle-associated") in floating foams, the SML and the underlying water since Cand. Patescibacteria in the $0.2-3 \mu \mathrm{m}$ fraction are rather objects for aerosolization due to their small size, while in the $>3 \mu \mathrm{m}$ fraction they are more likely to live symbiotic or to adhere to organic material.

\section{Experiments}

Cell count and 16S rRNA amplicon data for this study were extracted and re-analyzed from a previous study [27]. Samples of foam, SML and underlying, i.e., $1 \mathrm{~m}$ deep water were sampled in the Jade Bay, North Sea, offshore Wilhelmshaven, Germany (Figure 1). SML and floating foams (Figure 1) were collected using the glass plate method [32], and the glass plate rinsed with $70 \%$ ethanol. Underlying water from $1 \mathrm{~m}$ depth was sampled with a syringe connected to a weighted hose. For prokaryotic cell counts, samples were fixed with $1 \%$ final concentration of glutaraldehyde, incubated for $1 \mathrm{~h}$ at room temperature and frozen at $-80{ }^{\circ} \mathrm{C}$ until further processing. Due to their sticky nature and particle content, foam samples were pre-filtered by gravity onto CellTrics ${ }^{\circledR} 50 \mu \mathrm{m}$ mesh-size filters (Sysmex Partec, Muenster, Germany). Cells were stained with SYBR ${ }^{\circledR}$ Green I Nucleic Acid Gel Stain (9x in final concentration, Thermo Fisher Scientific, Darmstadt, Germany) and measured on a flow cytometer (C6 Flow-Cytometer, BD Bioscience, San Jose, CA, USA) following a protocol by Giebel, et al. [33]. Here, prokaryotes were gated/separated into high (HNA) and low (LNA) nucleic acid content cells according to Proctor, et al. [34], assuming that the LNA type contains small genomes [35] and thus includes Cand. Patescibacteria. 


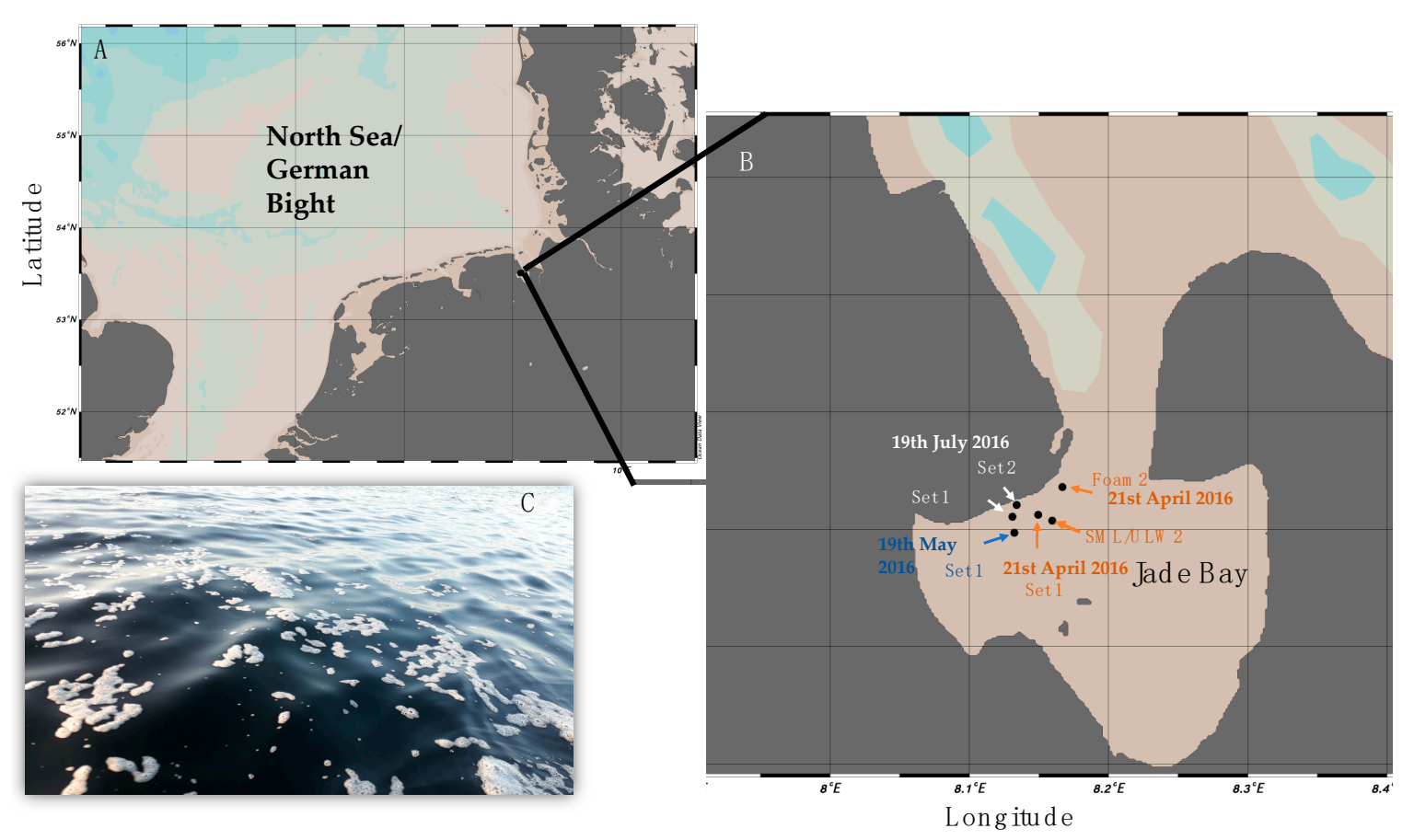

Figure 1. (A) Sampling stations in the Jade Bay, North Sea/German Bight, Germany; (B) A whole sampling set refers to foam/sea-surface microlayer (SML)/1-m depth = underlying water (ULW). As indicated, on one occasion foam and SML/ULW were collected in different places. Coordinates for Set 2 from 19 May 2016 are missing. (C) The occurrence of patchy sea foam floating at the sea surface (Photo: Janina Rahlff). Map was generated using Ocean Data View [36].

Samples were sequentially filtered onto $3 \mu \mathrm{m}$ and $0.2 \mu \mathrm{m}$ polycarbonate filter membranes (Merck Millipore, Darmstadt, Germany). Extraction of DNA and RNA were simultaneously performed using the DNA + RNA + Protein Extraction Kit (Roboklon, Berlin, Germany) with slight modifications from the manufacturer's protocol [37]. Remaining genomic DNA in RNA samples was digested on-column with $3 \mathrm{U}$ of DNase, and RNA was used in a PCR to check for further contamination with DNA. Synthesis of cDNA was performed using the NG dART Kit (Roboklon, Berlin, Germany), $10 \mathrm{ng}$ of RNA and the primer 1492R (5'-GGTTACCTTGTTACGACTT-3', [38]) in a run of $60 \mathrm{~min}$. at $50^{\circ} \mathrm{C}$ followed by $5 \mathrm{~min}$. at $85^{\circ} \mathrm{C}$. Quantification of DNA and cDNA concentrations was done using the Quant-iT $^{\mathrm{TM}}$ PicoGreen ${ }^{\mathrm{TM}}$ dsDNA assay (Thermo Fisher Scientific, Darmstadt, Germany). Amplicon and index PCR, subsequent quality checks, and sequencing of the bacterial 16S rRNA (gene) were conducted using Illumina MiSeq by a third-party service (Eurofins Genomics, Ebersberg, Germany). For amplicon PCR, 35 and 25 cycles were done for DNA and cDNA templates, respectively and by using the primer set Bakt_341F/805R [39].

Paired-end sequence reads were assembled using QIIME 1.9.1 [40] and evaluated using the SILVA NGS pipeline [41] including quality checks in compliance with SINA-based alignments [42], where PCR artifacts and non-SSU reads were excluded. Sequence reads were reanalyzed using SILVA SSU138 [4] as basis in ARB [43] and merging reads assigned to Cand. Patescibacteria without changing the global tree topology using the ARB parsimony tool. In the case of $98 \%$ sequence identity, classification of the ref sequence was mapped to all members of the respective cluster and to their replicates. The threshold for best BLAST hit acceptance was (sequence identity + alignment coverage) $/ 2 \geq 93 \%$, and otherwise assigned to "unclassified". Sequence reads were deposited in the European Nucleotide Archive (ENA) under accession number PRJEB34343. Representative assembled reads assigned to Cand. Patescibacteria were deposited at GenBank under accession number MW167660-MW167765. The number of Cand. Patescibacteria related OTUs was compared between the three different habitats, 
two nucleic acid types and two filtered fractions using a Kruskal-Wallis with a post hoc Tukey's HSD test to find for significant differences at the 95\% significance level using PAST [44].

\section{Results and Discussion}

Several studies investigated the dominant bacterial community composition of the SML and foam [45-48]. However, potentially due to their low abundance, patescibacterial ultramicrobacteria have been neglected in marine neuston habitats to date. In this study, we use the name Cand. Patescibacteria [49] to cover all sequences within the "superphylum" Candidate Phyla Radiation (CPR) as classified in the 16S rRNA database SILVA SSU 138 [4,50]. This also includes the candidate groups Microgenomates (OP11), Parcubacteria (OD1), WS6, WWE3, Candidatus Berkelbacteria, Peregrinibacteria, and Saccharibacteria (TM7). The separation of $>3 \mu \mathrm{m}$ for particle-associated (PA) and $0.2-3 \mu \mathrm{m}$ filtration for free-living (FL) bacteria is common practice in microbial ecology, although many ultra-small bacteria will pass $0.2 \mu \mathrm{m}$ filter (reviewed by Nakai [51,52]). However, members of the TM7 are described to change their cellular morphology from very small cocci to large filaments and are thereby captured by $>0.2$ um filtration [53]. In our study, we found 15-369 different OTUs (Figure 2) of 40 different Cand. Patescibacteria clades across all samples in a relative abundance between $0-1.4 \%$ of the total community (Figure 3).

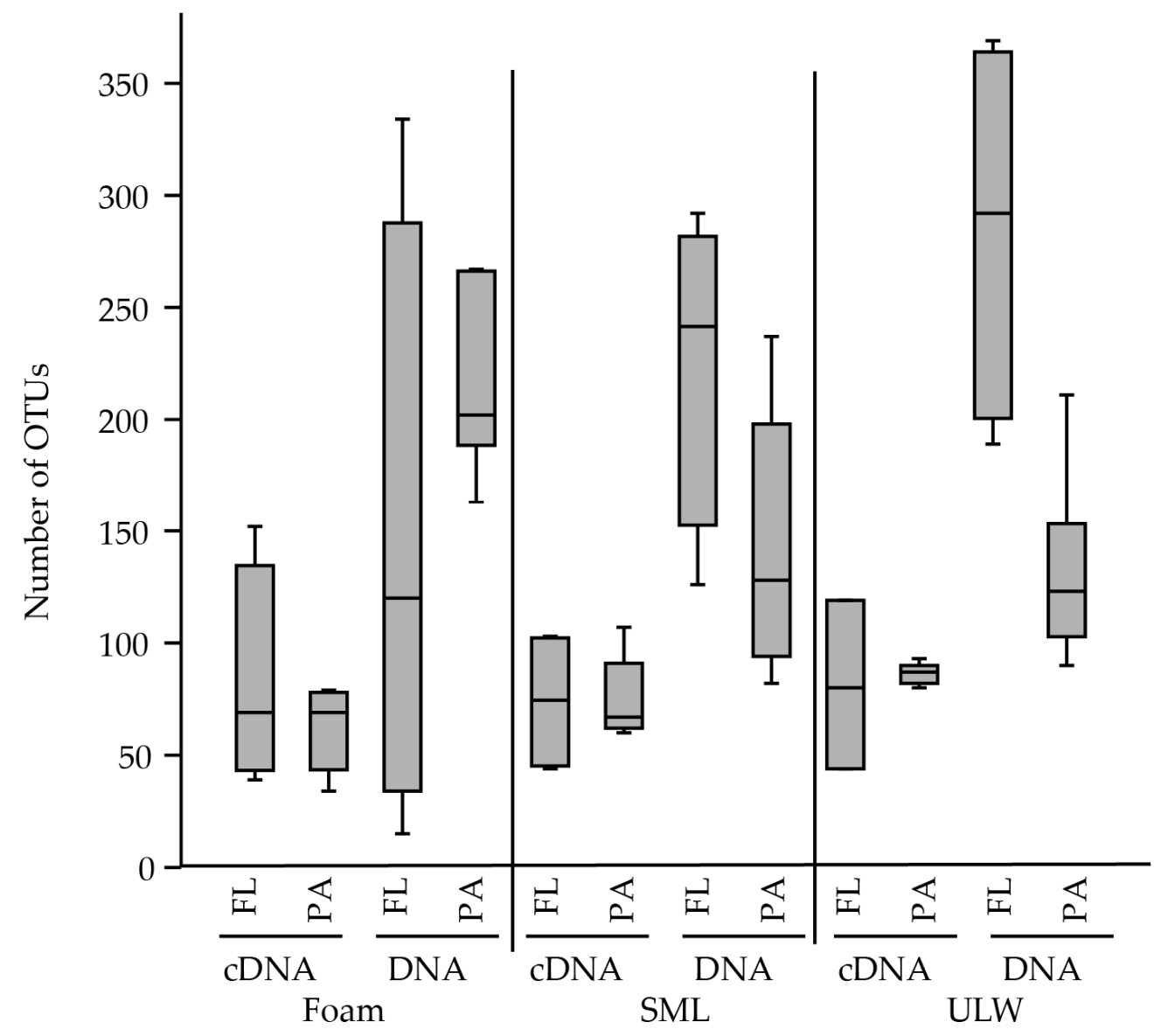

Figure 2. Median of patescibacterial OTUs per habitat, i.e., foam, sea-surface microlayer (SML) and underlying-water (ULW). Samples were further divided into free-living (FL) and particle-associated (PA). 


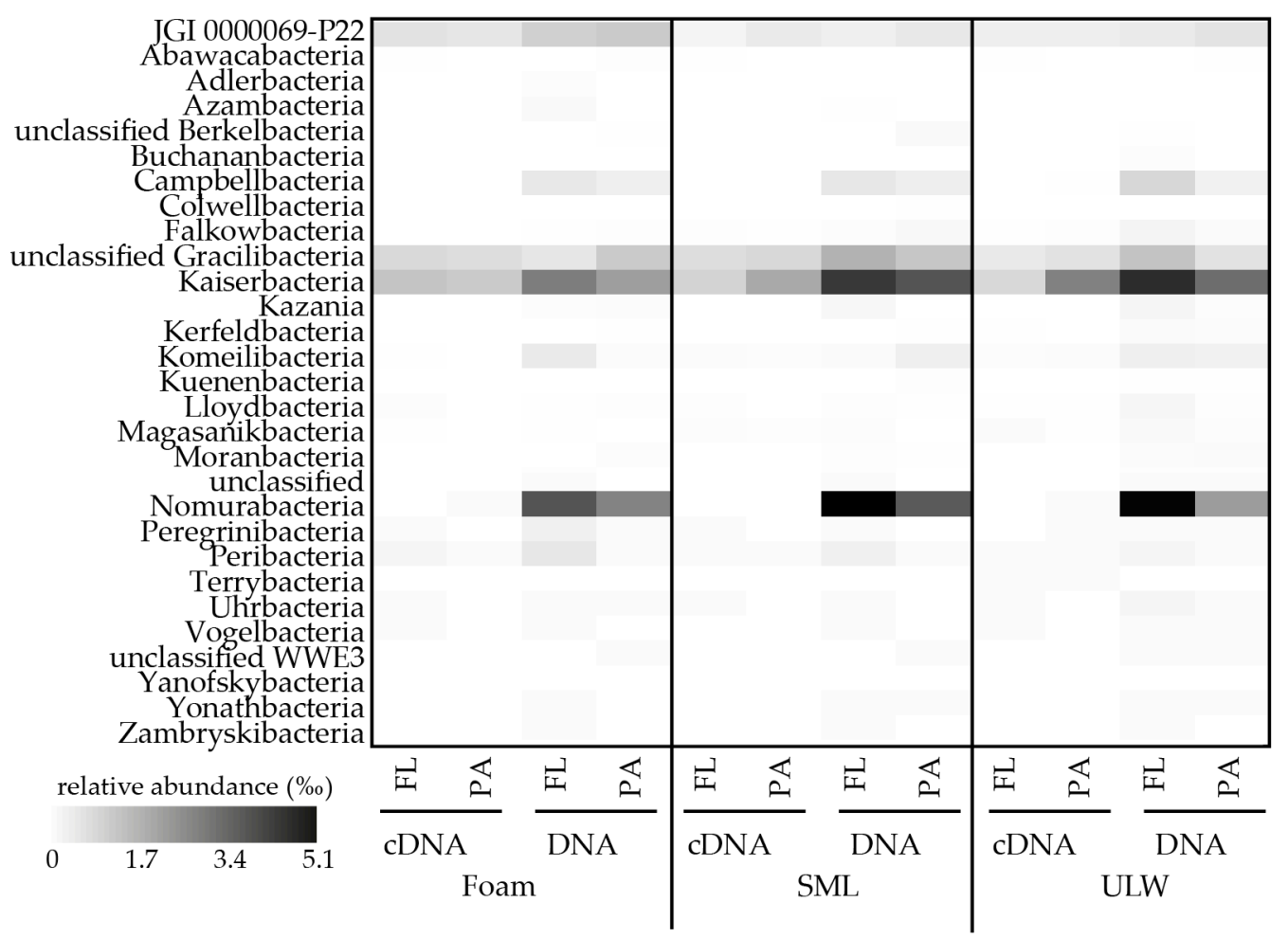

Figure 3. Heatmap showing relative abundance (\%o) of patescibacterial candidate clades for cDNA and DNA-derived amplicons in foam, sea-surface microlayer (SML) and underlying water (ULW). Samples were further divided into free-living (FL) and particle-associated (PA) fractions. Only lineages with $>10$ reads are shown.

Analysis of the flow cytometry samples, that are unfiltered, revealed an average LNA portion of $38 \%( \pm 16.8 \%), 60 \%( \pm 24.2 \%)$, and $56 \%( \pm 22.1 \%)$ in foams, SML and $1 \mathrm{~m}$ deep water, respectively (Table A1 in Appendix A, Figure 4). Due to their small genomes, the LNA fraction probably comprised Cand. Patescibacteria [34] suggesting a higher abundance in these fractions as detected by amplicon sequencing. However, in addition to Cand. Patescibacteria other LNA bacteria like SAR11 might also be present [54], and more detailed analyses will be necessary to estimate the total abundance of Cand. Patescibacteria. In addition to the filtration bias, universal 16S RNA primer and protocols do not cover the complete bacterial diversity and up to $20 \%$ of environmental bacterial sequences are missing $[2,55]$. Mismatch analyses of our primer set in ARB SILVA [56] revealed little coverage of the Microgenomates, one of the major orders of Cand. Patescibacteria (Figure A1). In SILVA Ref NR 138 a total of 4543 sequences are assigned to the Cand. Patescibacteria, of which the primers Bakt_341F/805R [39] used in this analysis matched 2618 of these sequences (58\%, Figure A1). Bakt_341F/805R primers cover Cand. Parcubacteria (OD1) sufficiently [57], but only a small set (37\%) of the Cand. Kaiserbacteria can be amplified (Figure A2). Interestingly, Cand. Kaiserbacteria were one of the most abundant groups in our study. Cand. Gracilibacteria, the most diverse group in our analysis were fairly well covered (81\%) next to Cand. Peribacteria (Figure A3). Filtration and primer biases cause that the presented Cand. Patescibacteria abundances and especially of Cand. Kaiserbacteria are probably underestimated. Metagenomic sequencing approaches are advantageous concerning primer biases. However, current sequencing depth in metagenomics only cover the most abundant bacterial lineages and has only limited quantitative information. In addition, the presence of small eukaryotic organisms, like phytoplankton in surface water, causes a high number of non-target metagenomic sequences and an amplification of bacterial DNA therefore seemed feasible in this study. 
A
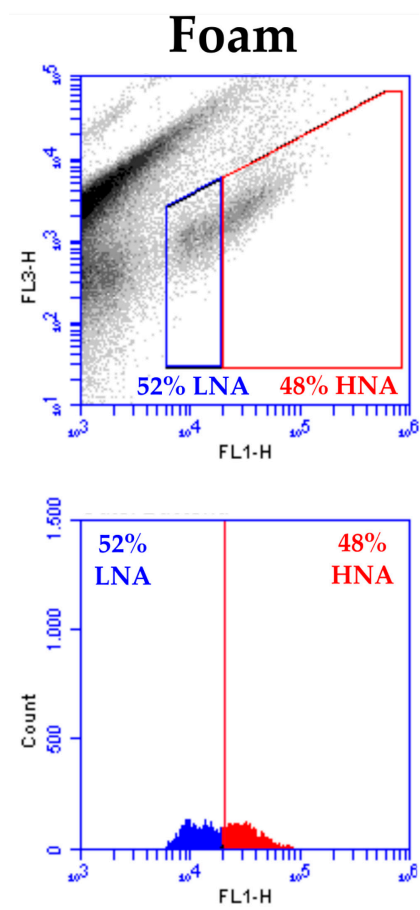

B
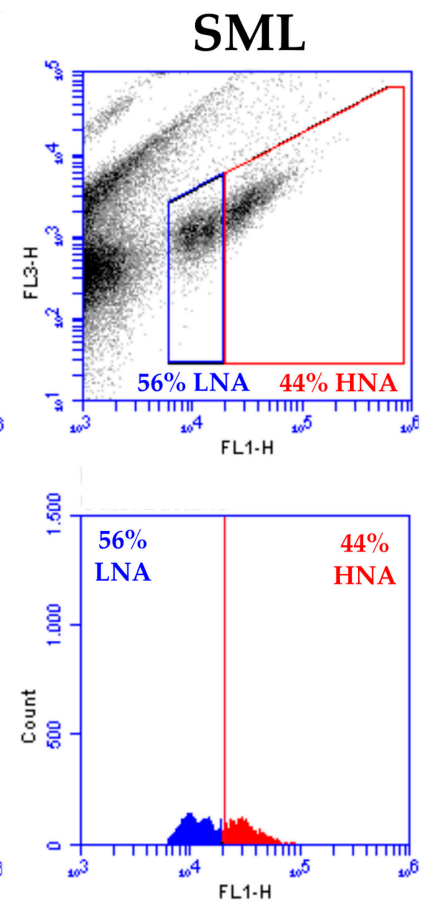

C
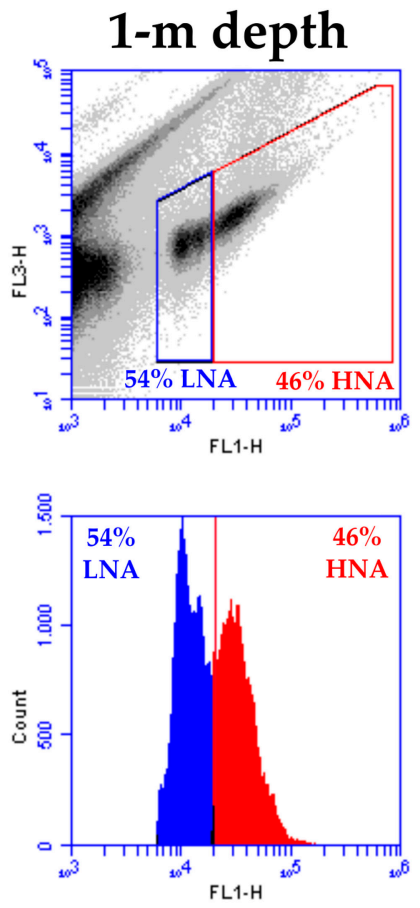

Figure 4. Representative example of high nucleic acid (HNA) and low nucleic acid (LNA) cells in (A) foam, (B) sea-surface microlayer (SML), (C) 1-m depth samples from 21st April 2016 (Set 2). Here, more than half of all bacterial cells belong to LNA cells and potentially include Cand. Patescibacteria having small genomes.

In marine surface water at $1 \mathrm{~m}$ depth (total Cand. Patescibacteria abundance 2.1-13.6\%o of assigned bacterial reads), in the SML (total Cand. Patescibacteria abundance 2.4-12.6\%o of assigned bacterial reads), and in foams (total Cand. Patescibacteria abundance 2.4-9.7\%o of assigned bacterial reads) floating at the air-sea interface Cand. Nomurabacteria and Cand. Kaiserbacteria as well as JGI 0000069-P22 and unclassified Gracilibacteria were the most abundant phylogenetic lineages (Figure 3). By clustering our sequences with the SILVA Ref seq database and considering the marine or aerosol origin of deposited sequence information, we found similarities of assembled reads from this study to previously detected sequences assigned to Cand. Patescibacteria (Table 1, Supplementary Figure S1). Many sequences of marine origin were derived from meromictic waters, sampled in coastal proximity or from a lagoon [58]. Generally, Cand. Patescibacteria are frequently described in stratified freshwater lakes [18,57-59], suggesting that they might generally thrive in calmed water, where stagnant conditions could favor facultative symbiotic attachment. This explains the relatively low abundance at the air-sea interface where wind-wave dynamics often lead to profound mixing, which is known to inhibit abundance and activity of certain SML-populating bacteria [37]. However, other studies reported that Cand. Patescibacteria are quite responsive and adaptive to changing environments [10] a characteristic favoring their presence at the air-sea boundary. In our study, more OTUs were present in the DNA compared to cDNA-based samples (Figure 2), which is supported by statistical analysis (Table A2). For instance, the number of patescibacterial OTUs was significantly different for DNA-based amplicons of the free-living $1 \mathrm{~m}$ deep fractions compared to all cDNA-derived samples from all three habitats (Tukey's HSD, maximum $p$-value $=1.60 \times 10^{-3}$ ). The minor detection of Cand. Patescibacteria among the cDNA-derived amplicons suggests that most Cand. Patescibacteria are rather senescent and have an inactive lifestyle. This especially applies to Cand. Nomurabacteria, which were more abundant (range $2.0-5.1 \%$ o) based on $16 \mathrm{~S}$ rRNA gene-based amplicons but hardly detectable among rRNA-based amplicons. 
Table 1. Sequences related to Cand. Patescibacteria of marine surface water or atmospheric origin. Sequences were detected based on phylogenetic clustering with samples from this study.

\begin{tabular}{|c|c|c|c|c|c|}
\hline $\begin{array}{l}\text { NCBI Accession \# of } \\
\text { Sequences from This } \\
\text { Study }\end{array}$ & $\begin{array}{c}\text { NCBI Accession \# of } \\
\text { Phylogenetic Neighbor } \\
\text { from Surface } \\
\text { Water/Aerosol }\end{array}$ & Sequence Name & Origin & Phylogenetic Affiliation & Reference \\
\hline MW167728, MW167751 & HQ691922 & $\begin{array}{l}\text { Uncultured bacterium, 1327, } \\
\text { stratified lagoon }\end{array}$ & $\begin{array}{l}\text { Clipperton Island atoll, North Pacific Ocean, } \\
\text { Meromictic lagoon, marine }\end{array}$ & JGI 0000069-P22 & [60] \\
\hline $\begin{array}{l}\text { MW167732, MW167737, } \\
\text { MW167759, MW167763 }\end{array}$ & HQ691923 & $\begin{array}{l}\text { Uncultured bacterium, 1317, } \\
\text { stratified lagoon }\end{array}$ & $\begin{array}{l}\text { Clipperton Island atoll, North Pacific Ocean, } \\
\text { Meromictic lagoon, marine }\end{array}$ & JGI 0000069-P22 & [60] \\
\hline $\begin{array}{l}\text { MW167705, MW167707, } \\
\text { MW167722 }\end{array}$ & HQ691924 & $\begin{array}{l}\text { Uncultured bacterium, } 1276 \text {, } \\
\text { stratified lagoon }\end{array}$ & $\begin{array}{l}\text { Clipperton Island atoll, North Pacific Ocean, } \\
\text { Meromictic lagoon, marine }\end{array}$ & Cand. Peregrinibacteria & [60] \\
\hline $\begin{array}{l}\text { MW167672, MW167678, } \\
\text { MW167694 }\end{array}$ & HQ691925 & $\begin{array}{l}\text { Uncultured bacterium, } 1288, \\
\text { stratified lagoon }\end{array}$ & $\begin{array}{l}\text { Clipperton Island atoll, North Pacific Ocean, } \\
\text { Meromictic lagoon, marine }\end{array}$ & Cand. Peribacteria & [60] \\
\hline $\begin{array}{l}\text { MW167669, MW167680, } \\
\text { MW167690 }\end{array}$ & HQ691926 & $\begin{array}{l}\text { Uncultured bacterium, 1318, } \\
\text { stratified lagoon }\end{array}$ & $\begin{array}{l}\text { Clipperton Island atoll, North Pacific Ocean, } \\
\text { Meromictic lagoon, marine }\end{array}$ & Cand. Peribacteria & [60] \\
\hline $\begin{array}{l}\text { MW167660, MW167688, } \\
\text { MW167703 }\end{array}$ & HQ691927 & $\begin{array}{l}\text { Uncultured bacterium, 1311, } \\
\text { stratified lagoon }\end{array}$ & $\begin{array}{l}\text { Clipperton Island atoll, North Pacific Ocean, } \\
\text { Meromictic lagoon, marine }\end{array}$ & Cand. Peribacteria & [60] \\
\hline $\begin{array}{l}\text { MW167675, MW167687, } \\
\text { MW167717 }\end{array}$ & HQ691928 & $\begin{array}{l}\text { Uncultured bacterium, 1323, } \\
\text { stratified lagoon }\end{array}$ & $\begin{array}{l}\text { Clipperton Island atoll, North Pacific Ocean, } \\
\text { Meromictic lagoon, marine }\end{array}$ & Cand. Buchananbacteria & [60] \\
\hline $\begin{array}{l}\text { MW167683, MW167684, } \\
\text { MW167710, MW167736 }\end{array}$ & HQ691929 & $\begin{array}{l}\text { Uncultured bacterium, 1317, } \\
\text { stratified lagoon }\end{array}$ & $\begin{array}{l}\text { Clipperton Island atoll, North Pacific Ocean, } \\
\text { Meromictic lagoon, marine }\end{array}$ & Cand. Moranbacteria & [60] \\
\hline MW167686, MW167713 & HQ691930 & $\begin{array}{l}\text { Uncultured bacterium, 1328, } \\
\text { stratified lagoon }\end{array}$ & $\begin{array}{l}\text { Clipperton Island atoll, North Pacific Ocean, } \\
\text { Meromictic lagoon, marine }\end{array}$ & Cand. Magasanikbacteria & [60] \\
\hline $\begin{array}{l}\text { MW167715, MW167719, } \\
\text { MW167721 }\end{array}$ & HQ691931 & $\begin{array}{l}\text { Uncultured bacterium, 1359, } \\
\text { stratified lagoon }\end{array}$ & $\begin{array}{l}\text { Clipperton Island atoll, North Pacific Ocean, } \\
\text { Meromictic lagoon, marine }\end{array}$ & Cand. Magasanikbacteria & [60] \\
\hline MW167673, MW167689 & HQ691932 & $\begin{array}{l}\text { Uncultured bacterium, 1323, } \\
\text { stratified lagoon }\end{array}$ & $\begin{array}{l}\text { Clipperton Island atoll, North Pacific Ocean, } \\
\text { Meromictic lagoon, marine }\end{array}$ & Cand. Komeilibacteria & [60] \\
\hline $\begin{array}{l}\text { MW167674, MW167704, } \\
\text { MW167711 }\end{array}$ & HQ691933 & $\begin{array}{l}\text { Uncultured bacterium, 1333, } \\
\text { stratified lagoon }\end{array}$ & $\begin{array}{l}\text { Clipperton Island atoll, North Pacific Ocean, } \\
\text { Meromictic lagoon, marine }\end{array}$ & Cand. Komeilibacteria & [60] \\
\hline MW167671, MW167699 & HQ691934 & $\begin{array}{l}\text { Uncultured bacterium, 1395, } \\
\text { stratified lagoon }\end{array}$ & $\begin{array}{l}\text { Clipperton Island atoll, North Pacific Ocean, } \\
\text { Meromictic lagoon, marine }\end{array}$ & Cand. Falkowbacteria & [60] \\
\hline MW167663, MW167666 & AACY023814357 & $\begin{array}{l}\text { Marine metagenome, } 1412, \\
\text { predominantly from surface water } \\
\text { marine samples }\end{array}$ & $\begin{array}{l}\text { Surface water samples, off the coast of } \\
\text { Bermuda, marine }\end{array}$ & Cand. Falkowbacteria & [61] \\
\hline MW167720 & AACY023758110 & $\begin{array}{l}\text { Marine metagenome, } 1295, \\
\text { predominantly from surface water } \\
\text { marine samples }\end{array}$ & $\begin{array}{l}\text { Surface water samples, off the coast of } \\
\text { Bermuda, marine }\end{array}$ & Cand. Kuenenbacteria & [61] \\
\hline $\begin{array}{l}\text { MW167725, MW167733, } \\
\text { MW167749 }\end{array}$ & AACY023749576 & $\begin{array}{l}\text { Marine metagenome, } 1409 \text {, } \\
\text { predominantly from surface water } \\
\text { marine samples }\end{array}$ & $\begin{array}{l}\text { Surface water samples, off the coast of } \\
\text { Bermuda, marine }\end{array}$ & JGI 0000069-P22 & [61] \\
\hline
\end{tabular}


Table 1. Cont

\begin{tabular}{|c|c|c|c|c|c|}
\hline $\begin{array}{l}\text { NCBI Accession \# of } \\
\text { Sequences from This } \\
\text { Study }\end{array}$ & $\begin{array}{c}\text { NCBI Accession \# of } \\
\text { Phylogenetic Neighbor } \\
\text { from Surface } \\
\text { Water/Aerosol }\end{array}$ & Sequence Name & Origin & Phylogenetic Affiliation & Reference \\
\hline $\begin{array}{l}\text { MW167667, MW167676, } \\
\text { MW167679, MW167691 }\end{array}$ & AACY020292957 & $\begin{array}{l}\text { Marine metagenome, } 1318 \\
\text { predominantly from surface water } \\
\text { marine samples }\end{array}$ & $\begin{array}{l}\text { Surface water samples, off the coast of } \\
\text { Bermuda, marine }\end{array}$ & Cand. Kaiserbacteria & {$[61]$} \\
\hline $\begin{array}{l}\text { MW167670, MW167692, } \\
\text { MW167695, MW167696 }\end{array}$ & AACY023772748 & $\begin{array}{l}\text { Marine metagenome, } 1245 \\
\text { predominantly from surface water } \\
\text { marine samples }\end{array}$ & $\begin{array}{l}\text { Surface water samples, off the coast of } \\
\text { Bermuda, marine }\end{array}$ & Cand. Gracilibacteria & {$[61]$} \\
\hline $\begin{array}{l}\text { MW167731, MW167744, } \\
\text { MW167765 }\end{array}$ & GU235593 & $\begin{array}{l}\text { Uncultured marine bacterium, } 1328, \\
\text { Antarctic sea water collected from } \\
5 \mathrm{~m}\end{array}$ & $\begin{array}{l}\text { Antarctic sea water collected from } 5 \mathrm{~m} \text {, } \\
\text { coastal surface waters at Palmer Station, } \\
\text { on the west coast of the Antarctic Peninsula }\end{array}$ & JGI 0000069-P22 & [62] \\
\hline $\begin{array}{l}\text { MW167727, MW167734, } \\
\text { MW167735, MW167747, } \\
\text { MW167748, MW167756 }\end{array}$ & GU234860 & $\begin{array}{l}\text { Uncultured marine bacterium, } 1316 \text {, } \\
\text { Antarctic sea water collected from } \\
5 \mathrm{~m}\end{array}$ & $\begin{array}{l}\text { Antarctic sea water collected from } 5 \mathrm{~m} \text {, } \\
\text { coastal surface waters at Palmer Station, } \\
\text { on the west coast of the Antarctic Peninsula }\end{array}$ & JGI 0000069-P22 & [62] \\
\hline MW167726, MW167740 & LN681284 & $\begin{array}{l}\text { Bacterium RFB D08, 1233, marine } \\
\text { alga }\end{array}$ & $\begin{array}{l}\text { Ria Formosa tidal pools close to the } \\
\text { Ramalhete Marine Station, marine }\end{array}$ & JGI 0000069-P22 & [63] \\
\hline $\begin{array}{l}\text { MW167668, MW167685, } \\
\text { MW167700 }\end{array}$ & FJ744790 & $\begin{array}{l}\text { Uncultured bacterium, 1397, } \\
\text { surface water at the UGA Marine } \\
\text { Institute }\end{array}$ & $\begin{array}{l}\text { Coastal water samples were collected high } \\
\text { tide from Sapelo Island, GA, marine }\end{array}$ & Cand. Gracilibacteria & [64] \\
\hline $\begin{array}{l}\text { MW167677, MW167701, } \\
\text { MW167716 }\end{array}$ & DQ269061 & $\begin{array}{l}\text { Uncultured bacterium, 1342, } \\
\text { surface of marine macro-alga }\end{array}$ & $\begin{array}{l}\text { One of three sampling sites, Sydney, } \\
\text { Australia, marine }\end{array}$ & Cand. Gracilibacteria & [65] \\
\hline $\begin{array}{l}\text { MW167739, MW167743, } \\
\text { MW167757 }\end{array}$ & FJ826108 & $\begin{array}{l}\text { Uncultured marine bacterium, } 1418 \text {, } \\
\text { filtered surface sea water }\end{array}$ & $\begin{array}{l}\text { Filtered surface sea water in the decay period } \\
\text { after diatom bloom in the Yellow Sea, marine }\end{array}$ & Cand. Peregrinibacteria & {$[66]$} \\
\hline $\begin{array}{l}\text { MW167739, MW167743, } \\
\text { MW167757 }\end{array}$ & FJ826198 & $\begin{array}{l}\text { Uncultured marine bacterium, 1442, } \\
\text { filtered surface sea water }\end{array}$ & $\begin{array}{l}\text { Filtered surface sea water in the decay period } \\
\text { after diatom bloom in the Yellow Sea, marine }\end{array}$ & Cand. Peregrinibacteria & {$[66]$} \\
\hline MW167681 & KU578668 & $\begin{array}{l}\text { Uncultured bacterium, } 1369 \text {, } \\
\text { ocean water }\end{array}$ & Marine & Cand. Magasanikbacteria & unpublished \\
\hline $\begin{array}{l}\text { MW167681, MW167697, } \\
\text { MW167702, MW167712 }\end{array}$ & FLOH01000114 & Marine metagenome, 1479 , water & Marine & Cand. Magasanikbacteria & not specified \\
\hline $\begin{array}{l}\text { MW167664, MW167714, } \\
\text { MW167718 }\end{array}$ & CEVN01160041 & $\begin{array}{l}\text { Marine metagenome, 1440, saline } \\
\text { water (ENVO:00002010), including } \\
\text { plankton (ENVO:xxxxxxxx) }\end{array}$ & Marine & Cand. Kaiserbacteria & not specified \\
\hline $\begin{array}{l}\text { MW167661, MW167665, } \\
\text { MW167698 }\end{array}$ & JQ197106 & $\begin{array}{l}\text { Uncultured bacterium, 1330, } \\
\text { seawater; next to dolphin E }\end{array}$ & Marine & Cand. Nomurabacteria & [67] \\
\hline $\begin{array}{l}\text { MW167693, MW167708, } \\
\text { MW167709 }\end{array}$ & JQ198499 & $\begin{array}{l}\text { Uncultured bacterium, } 1329 \\
\text { seawater; next to dolphin K }\end{array}$ & Marine & Cand. Nomurabacteria & [67] \\
\hline $\begin{array}{l}\text { MW167745, MW167746, } \\
\text { MW167753 }\end{array}$ & JN981903 & $\begin{array}{l}\text { Uncultured beta proteobacterium, } \\
\text { 1495, aerosols from orbal oxidation } \\
\text { ditch in a municipal WWTP }\end{array}$ & $\begin{array}{l}\text { Aerosols from orbal oxidation ditch in a } \\
\text { municipal WWTP }\end{array}$ & Cand. Gracilibacteria & [68] \\
\hline
\end{tabular}


In contrast to other studies reporting on $>20 \%$ Cand. Patescibacteria in the $0.2 \mu \mathrm{m}$ fraction for a peatland permafrost thaw lake [16] or in the suboxic hypolimnion of boreal lakes [57], we detected a maximum relative abundance of $1.2-1.4 \%$ of Cand. Patescibacteria in SML and surface water sample filtered onto a $0.2 \mu \mathrm{m}$ pore size filter membrane. Since marine surface water, the SML and foams represent aerobic environments, and despite facultative anaerobic bacteria inhabiting the SML [69], the Cand. Patescibacteria found in our study are most likely aerobic or at least aerotolerant. Considering these differences in abundance, Cand. Patescibacteria are presumably better adapted to freshwater ecosystems and low oxygen environments. The ultrasmall Cand. Patescibacteria were also detected on $>3 \mu \mathrm{m}$ filter membranes (Figure 3). This suggests that members of this phylum may also adhere to particles or are symbiotic with organisms on particles. Particles are especially enriched in the SML and foams $[28,70,71]$ and could serve Cand. Patescibacteria as a food source. Moreover, aggregates can form low oxygen microenvironments [72,73] allowing Cand. Patescibacteria to thrive, though these anoxic microzones might be too short-lived for slow-growing anaerobic microorganisms to take advantage [73]. Our results show that Cand. Kaiserbacteria and Cand. Gracilibacteria were metabolically active based at the time of their detection as their respective 16S rRNAs were detected and thus represent potential candidates for living in anoxic particles. However, the proposed restricted biosynthetic capabilities may also favor a symbiotic lifestyle [20]. Searching the SILVA Ref 138 database for related sequences revealed that several sequences of Cand. Patescibacteria were previously found on microbial communities associated with marine algae, e.g., Cand. Gracilibacteria (Table 1). Since algae are integral parts of marine foams in the $>3 \mu \mathrm{m}$ fraction [74], and can be trapped within them [75], members of Cand. Patescibacteria may therefore be symbionts of eukaryotic hosts as described earlier [76].

Cand. Patescibacteria have been shown to scavenge organic compounds, e.g., lipids $[10,77]$ or nucleotides from external sources and other organisms [10,78], because they lack the required metabolic pathways for de novo biosynthesis. In addition, Vigneron, Cruaud, Langlois, Lovejoy, Culley and Vincent [16] suggested that they have the metabolic capacity for amylose and cellulose degradation since the group of glycoside hydrolase enzymes are part of their metabolism. This supports their role in the degradation of refractory organic matter and, therefore, in the marine carbon cycling. Saccharibacteria, which have cultivated representatives $[79,80]$, were predicted to utilize glucose, amino acids and plant-derived carbon compounds [78,81], substances that are typically found in foams [82-84]. Therefore, despite their low abundance, Cand. Patescibacteria might have a crucial role as specialists in degradation processes at the ocean's surface. Degradation of cells and matter could be further enhanced in the SML, because higher bacterial production compared to underlying water promotes lytic viral infections releasing carbon compounds [85]. Strong exposure to solar and ultraviolet radiation is detrimental for bacterioplankton [86]. Even if compensated by some resistance of the bacterioneuston to solar radiation [87], the high irradiance at the air-sea boundary will enhance turnover of cells and release of their content. At the same time, photolysis increases the bioavailability of recalcitrant dissolved organic matter [88]. All these processes support nutrient-scavenging organisms such as Cand. Patescibacteria, which heavily rely on external sources for all sorts of molecular building blocks, especially if these ultramicrobacteria do not parasitize a host [6]. In the marine realm, genomic and proteomic approaches combined with cultivation attempts and microscopic methods, e.g., by using organism-specific in situ probing, would be the best approaches to study Cand. Patescibacteria, and most knowledge on the clades detected in this study originate from genome-resolved metagenomics. Cultivation attempts of Cand. Patescibacteria have been rarely successful for many reasons such as their complicated interactions with multiple eukaryotic hosts [76], lethality to the host [89] or uncharacterized host ranges [90]. In addition, advanced techniques at the single-cell level such as reverse genomics have to be considered for the establishment of pure cultures [80].

Marine foams and the SML are both enriched in organic matter and nutrients [91-93], but can also be considered as challenging habitats due to accumulating pollutants (reviewed by Wurl and Obbard [91,94]) and prevailing effects of meteorological impacts [48,95]. Transport of living and 
non-living matter to the air-sea interface is mainly achieved by rising bubbles [96], mixing processes, or the result of atmospheric deposition [97]. At the same time, the SML is a known source for aerosolization of viruses and bacteria to the atmosphere [98] as reviewed by Rahlff [99]. Aerosolization from the SML seems to be very taxon-specific [100]. Therefore, depending on their own and/or their symbiotic partners aerosolization capacities, Cand. Patescibacteria might be transferred from $1 \mathrm{~m}$ depth to the SML by rising bubbles and from the SML to sea-spray aerosols. Observations on many rare and uncultured OTUs among airborne bacteria in a coastal region of the Baltic Sea [101], and higher contributions of less abundant seawater bacterial taxa being selectively transferred to marine aerosols [102] make signatures of Cand. Patescibacteria in marine aerosols very likely. In fact, preliminary data indicate the presence of Cand. Perigrinibacteria and Cand. Abscondibacteria in aerosol samples, which were artificially generated in a tank experiment during the EMB184 cruise using Baltic Sea surface water (unpublished data). Previous studies showed that aerosols produced by rotating brushes in a wastewater treatment plant were associated with a high portion of uncultured bacteria [68] including a sequence assigned to Cand. Gracilibacteria (Table 1). Furthermore, Cand. Patescibacteria were recently found in aerosols in the lower atmosphere of the Southern Ocean (7.8\%) [31], among aerosolized bacterial loads emitted by a green wall (dominated by the order Saccharimonadales (56.6\%)) [103], in blowing Arctic snow (0.2\% of OD1) [104], snow layers over sea ice $(\leq 0.3 \%$ of TM7) [105], and Arctic air with terrestrial source (24\% TM7) [106] and thus seem to potentially resist environmental conditions of the troposphere. Considering the usually low biomass associated with aerosol samples and the often-low portions of Cand. Patescibacteria in bacterial communities of marine surface waters, Cand. Patescibacteria likely remain underexplored and highly elusive components of the atmosphere. These ultra-small bacteria are rarely the target of sequencing efforts of marine surface water applying filtration protocols on pore sizes $>0.2 \mu \mathrm{m}$ and, if found, they are often not further classified [15,31]. Thus, here we can only speculate that Cand. Patescibacteria might experience transfer to the atmosphere from SML via sea spray aerosols, while their presence in foams suggests easy propagation to terrestrial ecosystems as foams get frequently dispersed to beaches by strong winds $[107,108]$.

\section{Conclusions}

Uncultivated bacteria of the Cand. Patescibacteria, also referred to as Candidate phyla radiation, were detected in small $(<1.3 \%)$ but probably underestimated quantities at the air-sea boundary (in the SML and foams) as well as in $1 \mathrm{~m}$ deep seawater. These findings support previous sequencing results on a diverse Cand. Patescibacteria bacterial community in the upper oceanic water column. Their peculiar lifestyle as symbionts might influence microbial communities and carbon cycling in the surface ocean, and by being further dispersed from these habitats, Cand. Patescibacteria might easily end up in the atmosphere and on land. Future work pursuing in situ localization combined with genome analyses as well as cultivation attempts are required to achieve a deeper understanding of the life strategies and underlying metabolic capacities of Cand. Patescibacteria at the ocean's surface.

Supplementary Materials: The following are available online at http://www.mdpi.com/2073-4433/11/11/1214/s1, Figure S1: Neighbor joining tree of Candidatus Patescibacteria sequences obtained from this and previous studies.

Author Contributions: Conceptualization, J.R. and D.P.R.H.; methodology, J.R., C.S., D.P.R.H.; formal analysis, J.R., D.P.R.H., H.-A.G.; investigation, J.R., C.S., O.W.; data curation, D.P.R.H., H.-A.G.; writing-original draft preparation, J.R., D.P.R.H.; writing-review and editing, J.R., H.-A.G., C.S., A.J.P., O.W., D.P.R.H.; visualization, J.R., H.-A.G., D.P.R.H.; supervision, C.S., D.P.R.H.; project administration, O.W.; funding acquisition, O.W. All authors have read and agreed to the published version of the manuscript.

Funding: J.R.: C.S., O.W. and this study were funded by the European Research Council project PASSME, grant number GA336408. The picture of seafoam was taken during a campaign funded by the Assemble Plus project MIDSEAS (European Union's Horizon 2020 research and innovation program, Grant Agreement No. 730984). D.P.R.H. was supported by the European Regional Development Fund/Estonian Research Council funded by "Mobilitas Plus Top Researcher grant MOBTT24". A.J.P. received funding by the Ministerium für Kultur und Wissenschaft des Landes Nordrhein-Westfalen ("Nachwuchsgruppe Alexander Probst"). The APC was funded by the Open Access Publication Fund of the University of Duisburg-Essen. 
Acknowledgments: We acknowledge technical assistance of Lisa Maria Engl. We also like to thank the ICBM workshop for arranging small boat operations in the Jade Bay. Further acknowledgements go to Isabel Stahmer, Tiera-Brandy Robinson, and Mariana Ribas-Ribas for assistance during water sampling, and to Mathias Wolterink for technical assistance in flow cytometry.

Conflicts of Interest: The authors declare no conflict of interest. The funders had no role in the design of the study; in the collection, analyses, or interpretation of data; in the writing of the manuscript, or in the decision to publish the results.

\section{Appendix A}

Table A1. Percentage (\%) of high nucleic acid (HNA) and low nucleic acid (LNA) in different sample sets. ULW = underlying water (refers to 1-m depth), SML = sea-surface microlayer.

\begin{tabular}{ccc}
\hline Sample & \%LNA & \%HNA \\
\hline ULW_21st_April_2016_set1 & 55.0 & 45.0 \\
SML_21st_April_2016_set1 & 76.9 & 23.1 \\
Foam_21st_April_2016_set1 & 42.5 & 57.5 \\
ULW_21st_April_2016_set2 & 53.7 & 46.3 \\
SML_21st_April_2016_set2 & 55.8 & 44.2 \\
Foam_21st_April_2016_set2 & 52.0 & 48.0 \\
ULW_19th_May_2016_set1 & 63.1 & 36.9 \\
SML_19th_May_2016_set1 & 62.5 & 37.5 \\
Foam_19th_May_2016_set1 & 32.5 & 67.5 \\
ULW_19th_May_2016_set2 & 65.0 & 35.0 \\
SML_19th_May_2016_set2 & 60.0 & 40.0 \\
Foam_19th_May_2016_set2 & 24.9 & 75.1 \\
ULW_19th_July_2016_set1 & 50.3 & 49.7 \\
SML_19th_July_2016_set1 & 49.7 & 50.3 \\
Foam_19th_July_2016_set1 & 39.8 & 60.2 \\
ULW_19th_July_2016_set2 & 51.6 & 48.4 \\
SML_19th_July_2016_set2 & 52.8 & 47.2 \\
Foam_19th_July_2016_set2 & 39.2 & 60.8 \\
\hline
\end{tabular}

Table A2. Results of statistical analysis for Figure 2. There was a significant difference between sample medians (Kruskal-Wallis Test, chi-squared: $36.14, p$-value $=1.6 \times 10^{-4}$ ). In this table, the upper diagonal reflects $p$-values after Tukey HSD test with significant results ( $p \leq 0.05$ indicated in orange) and Tukey's $\mathrm{Q}$ value in the lower diagonal. $\mathrm{FL}=$ free-living, $\mathrm{PA}=$ particle-associated, $\mathrm{SML}=$ sea-surface microlayer.

\begin{tabular}{|c|c|c|c|c|c|c|c|c|c|c|c|c|c|c|}
\hline & & & $\begin{array}{l}\text { Foam } \\
\text { cDNA }\end{array}$ & & DNA & & $\begin{array}{l}\text { SML } \\
\text { cDNA }\end{array}$ & & DNA & & $\begin{array}{l}\text { 1-m depth } \\
\text { cDNA }\end{array}$ & & DNA & \\
\hline & & & FL & PA & FL & PA & FL & PA & FL & PA & FL & PA & FL & PA \\
\hline \multirow[t]{3}{*}{ Foam } & cDNA & FL & & 1.00 & 0.90 & 0.03 & 1.00 & 1.00 & 0.04 & 0.89 & 1.00 & 1.00 & $5.43 \times 10^{-4}$ & 0.97 \\
\hline & DNA & FL & 2.26 & 3.11 & & 0.78 & 0.81 & 0.76 & 0.74 & 1.00 & 0.93 & 0.91 & 0.06 & 1.00 \\
\hline & & PA & 5.10 & 6.24 & 2.63 & & 0.02 & 0.01 & 1.00 & 0.56 & 0.07 & 0.02 & 0.77 & 0.34 \\
\hline \multirow[t]{3}{*}{ SML } & cDNA & FL & 0.29 & 0.43 & 2.55 & 5.42 & & 1.00 & 0.02 & 0.78 & 1.00 & 1.00 & $2.83 \times 10^{-4}$ & 0.92 \\
\hline & DNA & FL & 4.97 & 5.97 & 2.71 & 0.35 & 5.26 & 5.52 & & 0.55 & 0.08 & 0.03 & 0.94 & 0.35 \\
\hline & & PA & 2.31 & 3.27 & 0.16 & 3.12 & 2.63 & 2.78 & 3.13 & & 0.93 & 0.89 & 0.02 & 1.00 \\
\hline \multirow[t]{4}{*}{ 1-m depth } & cDNA & FL & 0.04 & 0.63 & 2.13 & 4.70 & 0.23 & 0.22 & 4.64 & 2.16 & & 1.00 & $1.60 \times 10^{-3}$ & 0.98 \\
\hline & & PA & 0.14 & 0.93 & 2.24 & 5.28 & 0.45 & 0.45 & 5.10 & 2.31 & 0.18 & & $3.16 \times 10^{-4}$ & 0.98 \\
\hline & DNA & FL & 7.07 & 8.18 & 4.81 & 2.64 & 7.36 & 7.73 & 2.10 & 5.43 & 6.58 & 7.31 & & 0.01 \\
\hline & & PA & 1.87 & 2.80 & 0.61 & 3.61 & 2.18 & 2.30 & 3.58 & 0.50 & 1.75 & 1.83 & 5.87 & \\
\hline
\end{tabular}




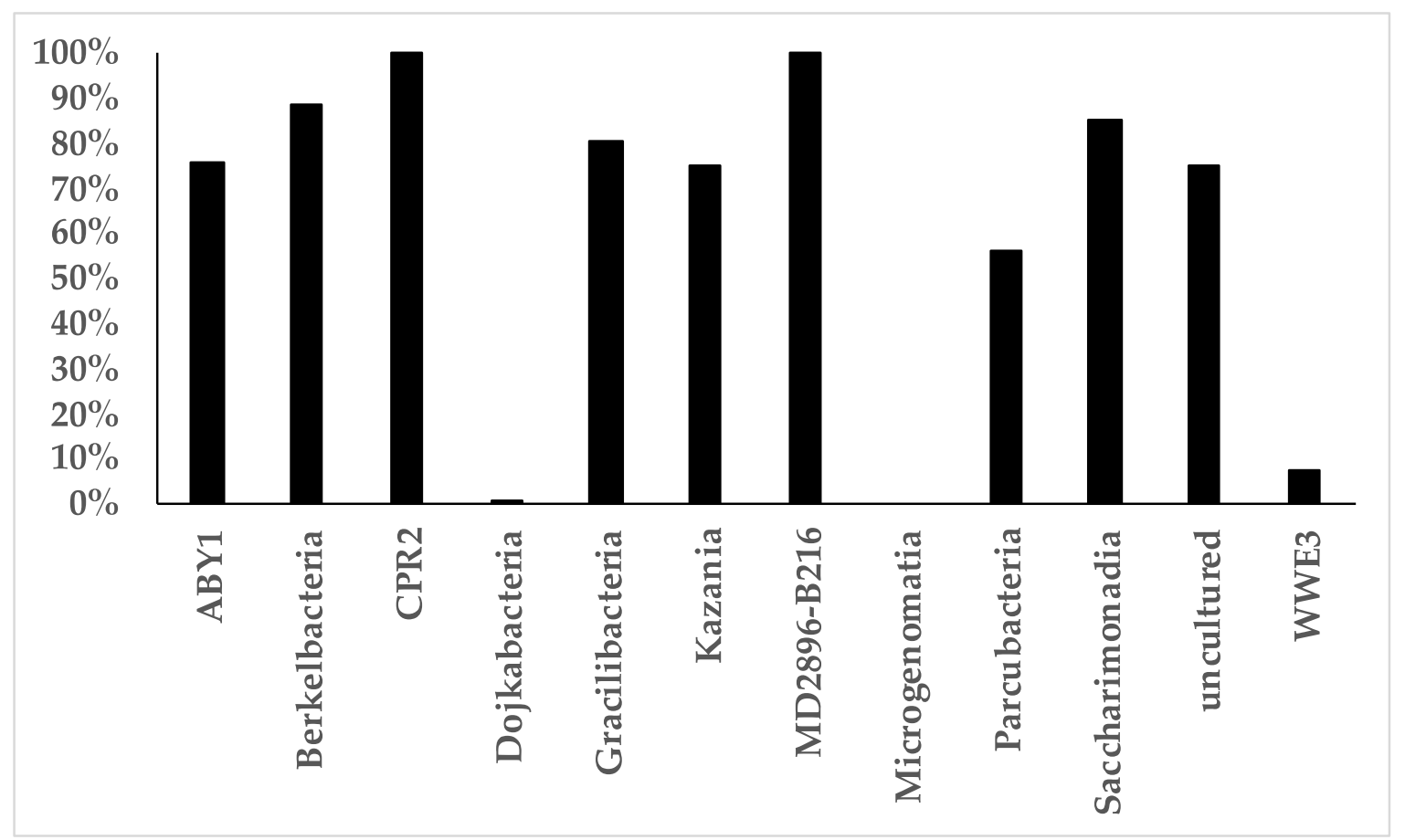

Figure A1. Coverage of primer set Bakt_341F/805R of various Cand. Patescibacteria clades and orders.



Figure A2. Coverage of primer set Bakt_341F/805R for various Cand. Parcubacteria clades (based on SILVA 138). 




Figure A3. Coverage of primer set Bakt_341F/805R for Cand. Gracilibacteria clades.

\section{References}

1. Parks, D.H.; Chuvochina, M.; Waite, D.W.; Rinke, C.; Skarshewski, A.; Chaumeil, P.A.; Hugenholtz, P. A standardized bacterial taxonomy based on genome phylogeny substantially revises the tree of life. Nat. Biotechnol. 2018, 36, 996-1004. [CrossRef] [PubMed]

2. Brown, C.T.; Hug, L.A.; Thomas, B.C.; Sharon, I.; Castelle, C.J.; Singh, A.; Wilkins, M.J.; Wrighton, K.C.; Williams, K.H.; Banfield, J.F. Unusual biology across a group comprising more than $15 \%$ of domain Bacteria. Nature 2015, 523, 208-211. [CrossRef] [PubMed]

3. Hug, L.A.; Baker, B.J.; Anantharaman, K.; Brown, C.T.; Probst, A.J.; Castelle, C.J.; Butterfield, C.N.; Hernsdorf, A.W.; Amano, Y.; Ise, K.; et al. A new view of the tree of life. Nat. Microbiol. 2016, 1, 16048. [CrossRef] [PubMed]

4. Quast, C.; Pruesse, E.; Yilmaz, P.; Gerken, J.; Schweer, T.; Yarza, P.; Peplies, J.; Glöckner, F.O. The SILVA ribosomal RNA gene database project: Improved data processing and web-based tools. Nucleic Acids Res. 2013, 41, D590-D596. [CrossRef]

5. Wrighton, K.C.; Thomas, B.C.; Sharon, I.; Miller, C.S.; Castelle, C.J.; VerBerkmoes, N.C.; Wilkins, M.J.; Hettich, R.L.; Lipton, M.S.; Williams, K.H.; et al. Fermentation, hydrogen, and sulfur metabolism in multiple uncultivated bacterial phyla. Science 2012, 337, 1661-1665. [CrossRef]

6. He, X.; McLean, J.S.; Edlund, A.; Yooseph, S.; Hall, A.P.; Liu, S.Y.; Dorrestein, P.C.; Esquenazi, E.; Hunter, R.C.; Cheng, G.; et al. Cultivation of a human-associated TM7 phylotype reveals a reduced genome and epibiotic parasitic lifestyle. Proc. Natl. Acad. Sci. USA 2015, 112, 244-249. [CrossRef] [PubMed] 
7. Lemos, L.N.; Medeiros, J.D.; Dini-Andreote, F.; Fernandes, G.R.; Varani, A.M.; Oliveira, G.; Pylro, V.S. Genomic signatures and co-occurrence patterns of the ultra-small Saccharimonadia (phylum CPR/Patescibacteria) suggest a symbiotic lifestyle. Mol. Ecol. 2019, 28, 4259-4271. [CrossRef]

8. Sieber, C.M.K.; Paul, B.G.; Castelle, C.J.; Hu, P.; Tringe, S.G.; Valentine, D.L.; Andersen, G.L.; Banfield, J.F. Unusual metabolism and hypervariation in the genome of a Gracilibacteria (BD1-5) from an oil-degrading community. mBio 2019, 10. [CrossRef]

9. Castelle, C.J.; Banfield, J.F. Major new microbial groups expand diversity and alter our understanding of the tree of life. Cell 2018, 172, 1181-1197. [CrossRef]

10. Castelle, C.J.; Brown, C.T.; Anantharaman, K.; Probst, A.J.; Huang, R.H.; Banfield, J.F. Biosynthetic capacity, metabolic variety and unusual biology in the CPR and DPANN radiations. Nat. Rev. Microbiol. 2018, 16, 629-645. [CrossRef]

11. Danczak, R.E.; Johnston, M.D.; Kenah, C.; Slattery, M.; Wrighton, K.C.; Wilkins, M.J. Members of the Candidate Phyla Radiation are functionally differentiated by carbon- and nitrogen-cycling capabilities. Microbiome 2017, 5, 112. [CrossRef] [PubMed]

12. Herrmann, M.; Wegner, C.E.; Taubert, M.; Geesink, P.; Lehmann, K.; Yan, L.; Lehmann, R.; Totsche, K.U.; Küsel, K. Predominance of Cand. Patescibacteria in groundwater is caused by their preferential mobilization from soils and flourishing under oligotrophic conditions. Front. Microbiol. 2019, 10, 1407. [CrossRef] [PubMed]

13. Nazina, T.N.; Babich, T.L.; Kostryukova, N.K.; Sokolova, D.S.; Abdullin, R.R.; Tourova, T.P.; Poltaraus, A.B.; Kalmykov, S.N.; Zakharova, E.V.; Myasoedov, B.F.; et al. Microbial diversity and possible activity in nitrateand radionuclide-contaminated groundwater. In Behavior of Radionuclides in the Environment I; Springer: Singapore, 2020; pp. 35-66. [CrossRef]

14. Probst, A.J.; Ladd, B.; Jarett, J.K.; Geller-McGrath, D.E.; Sieber, C.M.K.; Emerson, J.B.; Anantharaman, K.; Thomas, B.C.; Malmstrom, R.R.; Stieglmeier, M.; et al. Differential depth distribution of microbial function and putative symbionts through sediment-hosted aquifers in the deep terrestrial subsurface. Nat. Microbiol. 2018, 3, 328-336. [CrossRef] [PubMed]

15. Delmont, T.O.; Quince, C.; Shaiber, A.; Esen, O.C.; Lee, S.T.; Rappé, M.S.; McLellan, S.L.; Lücker, S.; Eren, A.M. Nitrogen-fixing populations of Planctomycetes and Proteobacteria are abundant in surface ocean metagenomes. Nat. Microbiol. 2018, 3, 804-813. [CrossRef] [PubMed]

16. Vigneron, A.; Cruaud, P.; Langlois, V.; Lovejoy, C.; Culley, A.I.; Vincent, W.F. Ultra-small and abundant: Candidate phyla radiation bacteria are potential catalysts of carbon transformation in a thermokarst lake ecosystem. Limnol. Oceanogr. Lett. 2019, 5, 212-220. [CrossRef]

17. Cabello-Yeves, P.J.; Zemskaya, T.I.; Zakharenko, A.S.; Sakirko, M.V.; Ivanov, V.G.; Ghai, R.; Rodriguez-Valera, F. Microbiome of the deep Lake Baikal, a unique oxic bathypelagic habitat. Limnol. Oceanogr. 2019, 65, 1471-1488. [CrossRef]

18. Borrel, G.; Lehours, A.C.; Bardot, C.; Bailly, X.; Fonty, G. Members of candidate divisions OP11, OD1 and SR1 are widespread along the water column of the meromictic Lake Pavin (France). Arch. Microbiol. 2010, 192, 559-567. [CrossRef]

19. Castelle, C.J.; Brown, C.T.; Thomas, B.C.; Williams, K.H.; Banfield, J.F. Unusual respiratory capacity and nitrogen metabolism in a Parcubacterium (OD1) of the Candidate Phyla Radiation. Sci. Rep. 2017, 7, 40101. [CrossRef]

20. Nelson, W.C.; Stegen, J.C. The reduced genomes of Parcubacteria (OD1) contain signatures of a symbiotic lifestyle. Front. Microbiol. 2015, 6, 713. [CrossRef]

21. Lannes, R.; Olsson-Francis, K.; Lopez, P.; Bapteste, E. Carbon fixation by marine ultrasmall prokaryotes. Genome Biol. Evol. 2019, 11, 1166-1177. [CrossRef]

22. Mustaffa, N.I.H.; Ribas-Ribas, M.; Banko-Kubis, H.M.; Wurl, O. Global reduction of in situ $\mathrm{CO}_{2}$ transfer velocity by natural surfactants in the sea-surface microlayer. Proc. Math. Phys. Eng. Sci. 2020, 476, 20190763. [CrossRef] [PubMed]

23. Flemming, H.C.; Wuertz, S. Bacteria and archaea on Earth and their abundance in biofilms. Nat. Rev. Microbiol. 2019, 17, 247-260. [CrossRef] [PubMed]

24. Wurl, O.; Stolle, C.; Van Thuoc, C.; Thu, P.T.; Mari, X. Biofilm-like properties of the sea surface and predicted effects on air-sea $\mathrm{CO}_{2}$ exchange. Prog. Oceanogr. 2016, 144, 15-24. [CrossRef] 
25. Cunliffe, M.; Engel, A.; Frka, S.; Gašparović, B.; Guitart, C.; Murrell, J.C.; Salter, M.; Stolle, C.; Upstill-Goddard, R.; Wurl, O. Sea surface microlayers: A unified physicochemical and biological perspective of the air-ocean interface. Progr. Oceanogr. 2013, 109, 104-116. [CrossRef]

26. Parks, G.; Dean, C.W.; Kluge, J.A.; Soloviev, A.V.; Shivji, M.; Tartar, A.; Howe, K.L.; Lehner, S.; Schwarz, E.; Shen, H.; et al. Analysis of surfactant-associated bacteria in the sea surface microlayer using deoxyribonucleic acid sequencing and synthetic aperture radar. Int. J. Remote Sens. 2020, 41, 3886-3901. [CrossRef]

27. Rahlff, J.; Stolle, C.; Giebel, H.-A.; Mustaffa, N.I.H.; Wurl, O.; Herlemann, D. Marine foams represent compressed sea-surface microlayer with distinctive bacterial communities. bioRxiv 2020. [CrossRef]

28. Schilling, K.; Zessner, M. Foam in the aquatic environment. Water Res. 2011, 45, 4355-4366. [CrossRef]

29. Carlson, D.J. Surface microlayer phenolic enrichments indicate sea surface slicks. Nature 1982, 296, 426-429. [CrossRef]

30. Hugoni, M.; Vellet, A.; Debroas, D. Unique and highly variable bacterial communities inhabiting the surface microlayer of an oligotrophic lake. Aquat. Microb. Ecol. 2017, 79, 115-125. [CrossRef]

31. Uetake, J.; Hill, T.C.J.; Moore, K.A.; DeMott, P.J.; Protat, A.; Kreidenweis, S.M. Airborne bacteria confirm the pristine nature of the Southern Ocean boundary layer. Proc. Natl. Acad. Sci. USA 2020, 117, 13275-13282. [CrossRef]

32. Harvey, G.W.; Burzell, L.A. A simple microlayer method for small samples. Limnol. Oceanogr. 1972, 17, 156-157. [CrossRef]

33. Giebel, H.A.; Wolterink, M.; Brinkhoff, T.; Simon, M. Complementary energy acquisition via aerobic anoxygenic photosynthesis and carbon monoxide oxidation by Planktomarina temperata of the Roseobacter group. FEMS Microbiol. Ecol. 2019, 95, fiz050. [CrossRef] [PubMed]

34. Proctor, C.R.; Besmer, M.D.; Langenegger, T.; Beck, K.; Walser, J.C.; Ackermann, M.; Burgmann, H.; Hammes, F. Phylogenetic clustering of small low nucleic acid-content bacteria across diverse freshwater ecosystems. ISME J. 2018, 12, 1344-1359. [CrossRef] [PubMed]

35. Bouvier, T.; Del Giorgio, P.A.; Gasol, J.M. A comparative study of the cytometric characteristics of high and low nucleic-acid bacterioplankton cells from different aquatic ecosystems. Environ. Microbiol. 2007, 9, 2050-2066. [CrossRef] [PubMed]

36. Schlitzer, R. Ocean Data View. Available online: https://odv.awi.de (accessed on 9 November 2020).

37. Rahlff, J.; Stolle, C.; Giebel, H.A.; Brinkhoff, T.; Ribas-Ribas, M.; Hodapp, D.; Wurl, O. High wind speeds prevent formation of a distinct bacterioneuston community in the sea-surface microlayer. FEMS Microbiol. Ecol. 2017, 93. [CrossRef]

38. Lane, D. 16S/23S rRNA Sequencing. In Nucleic Acid Techniques in Bacterial Systematics; Stackebrandt, E., Goodfellow, M., Eds.; John Wiley \& Sons: Chichester, UK, 1991; pp. 115-175.

39. Herlemann, D.P.; Labrenz, M.; Jürgens, K.; Bertilsson, S.; Waniek, J.J.; Andersson, A.F. Transitions in bacterial communities along the $2000 \mathrm{~km}$ salinity gradient of the Baltic Sea. ISME J. 2011, 5, 1571-1579. [CrossRef]

40. Caporaso, J.G.; Kuczynski, J.; Stombaugh, J.; Bittinger, K.; Bushman, F.D.; Costello, E.K.; Fierer, N.; Pena, A.G.; Goodrich, J.K.; Gordon, J.I.; et al. QIIME allows analysis of high-throughput community sequencing data. Nat. Methods 2010, 7, 335-336. [CrossRef]

41. Glöckner, F.O.; Yilmaz, P.; Quast, C.; Gerken, J.; Beccati, A.; Ciuprina, A.; Bruns, G.; Yarza, P.; Peplies, J.; Westram, R.; et al. 25 years of serving the community with ribosomal RNA gene reference databases and tools. J. Biotechnol. 2017, 261, 169-176. [CrossRef]

42. Pruesse, E.; Peplies, J.; Glöckner, F.O. SINA: Accurate high-throughput multiple sequence alignment of ribosomal RNA genes. Bioinformatics 2012, 28, 1823-1829. [CrossRef]

43. Ludwig, W.; Strunk, O.; Westram, R.; Richter, L.; Meier, H.; Yadhukumar; Buchner, A.; Lai, T.; Steppi, S.; Jobb, G.; et al. ARB: A software environment for sequence data. Nucleic Acids Res. 2004, 32, 1363-1371. [CrossRef]

44. Hammer, Ø.; Harper, D.A.; Ryan, P.D. PAST: Paleontological statistics software package for education and data analysis. Palaeontol. Electron. 2001, 4, 9.

45. Franklin, M.P.; McDonald, I.R.; Bourne, D.G.; Owens, N.J.; Upstill-Goddard, R.C.; Murrell, J.C. Bacterial diversity in the bacterioneuston (sea surface microlayer): The bacterioneuston through the looking glass. Environ. Microbiol. 2005, 7, 723-736. [CrossRef] [PubMed]

46. Druzhkov, N.V.; Makarevich, P.R.; Bardan, S.I. Sea foam as an object of sea-surface film studies. Polar Res. 1997, 16, 117-121. [CrossRef] 
47. Maynard, N.G. Aquatic foams as an ecological habitat. Z. Allg. Mikrobiol. 1968, 8, 119-126. [CrossRef] [PubMed]

48. Stolle, C.; Labrenz, M.; Meeske, C.; Jürgens, K. Bacterioneuston community structure in the southern Baltic sea and its dependence on meteorological conditions. Appl. Environ. Microbiol. 2011, 77, 3726-3733. [CrossRef] [PubMed]

49. Rinke, C.; Schwientek, P.; Sczyrba, A.; Ivanova, N.N.; Anderson, I.J.; Cheng, J.-F.; Darling, A.; Malfatti, S.; Swan, B.K.; Gies, E.A.; et al. Insights into the phylogeny and coding potential of microbial dark matter. Nature 2013, 499, 431-437. [CrossRef]

50. Yarza, P.; Yilmaz, P.; Pruesse, E.; Glöckner, F.O.; Ludwig, W.; Schleifer, K.H.; Whitman, W.B.; Euzéby, J.; Amann, R.; Rosselló-Móra, R. Uniting the classification of cultured and uncultured bacteria and archaea using 16S rRNA gene sequences. Nat. Rev. Microbiol. 2014, 12, 635-645. [CrossRef]

51. Nakai, R. Size Matters: Ultra-small and filterable microorganisms in the environment. Microbes Environ. 2020, 35, ME20025. [CrossRef]

52. Luef, B.; Frischkorn, K.R.; Wrighton, K.C.; Holman, H.Y.; Birarda, G.; Thomas, B.C.; Singh, A.; Williams, K.H.; Siegerist, C.E.; Tringe, S.G.; et al. Diverse uncultivated ultra-small bacterial cells in groundwater. Nat. Commun. 2015, 6, 6372. [CrossRef]

53. Bor, B.; Poweleit, N.; Bois, J.S.; Cen, L.; Bedree, J.K.; Zhou, Z.H.; Gunsalus, R.P.; Lux, R.; McLean, J.S.; $\mathrm{He}, \mathrm{X}$.; et al. Phenotypic and physiological characterization of the epibiotic interaction between TM7x and its basibiont Actinomyces. Microb. Ecol. 2016, 71, 243-255. [CrossRef]

54. Mary, I.; Heywood, J.L.; Fuchs, B.M.; Amann, R.; Tarran, G.A.; Burkill, P.H.; Zubkov, M.V. SAR11 dominance among metabolically active low nucleic acid bacterioplankton in surface waters along an Atlantic meridional transect. Aquat. Microb. Ecol. 2006, 45, 107-113. [CrossRef]

55. Eloe-Fadrosh, E.A.; Ivanova, N.N.; Woyke, T.; Kyrpides, N.C. Metagenomics uncovers gaps in amplicon-based detection of microbial diversity. Nat. Microbiol. 2016, 1, 15032. [CrossRef] [PubMed]

56. Pruesse, E.; Quast, C.; Knittel, K.; Fuchs, B.M.; Ludwig, W.; Peplies, J.; Glöckner, F.O. SILVA: A comprehensive online resource for quality checked and aligned ribosomal RNA sequence data compatible with ARB. Nucleic Acids Res. 2007, 35, 7188-7196. [CrossRef] [PubMed]

57. Peura, S.; Eiler, A.; Bertilsson, S.; Nykanen, H.; Tiirola, M.; Jones, R.I. Distinct and diverse anaerobic bacterial communities in boreal lakes dominated by candidate division OD1. ISME J. 2012, 6, 1640-1652. [CrossRef] [PubMed]

58. Gies, E.A.; Konwar, K.M.; Beatty, J.T.; Hallam, S.J. Illuminating microbial dark matter in meromictic Sakinaw Lake. Appl. Environ. Microbiol. 2014, 80, 6807-6818. [CrossRef]

59. Kadnikov, V.V.; Savvichev, A.S.; Mardanov, A.V.; Beletsky, A.V.; Merkel, A.Y.; Ravin, N.V.; Pimenov, N.V. Microbial communities involved in the methane cycle in the near-bottom water layer and sediments of the meromictic subarctic Lake Svetloe. Antonie Leeuwenhoek 2019, 112, 1801-1814. [CrossRef]

60. Galand, P.E.; Bourrain, M.; De Maistre, E.; Catala, P.; Desdevises, Y.; Elifantz, H.; Kirchman, D.L.; Lebaron, P. Phylogenetic and functional diversity of Bacteria and Archaea in a unique stratified lagoon, the Clipperton atoll (N Pacific). FEMS Microbiol. Ecol. 2012, 79, 203-217. [CrossRef]

61. Venter, J.C.; Remington, K.; Heidelberg, J.F.; Halpern, A.L.; Rusch, D.; Eisen, J.A.; Wu, D.; Paulsen, I.; Nelson, K.E.; Nelson, W.; et al. Environmental genome shotgun sequencing of the Sargasso Sea. Science 2004, 304, 66-74. [CrossRef]

62. Grzymski, J.J.; Riesenfeld, C.S.; Williams, T.J.; Dussaq, A.M.; Ducklow, H.; Erickson, M.; Cavicchioli, R.; Murray, A.E. A metagenomic assessment of winter and summer bacterioplankton from Antarctica Peninsula coastal surface waters. ISME J. 2012, 6, 1901-1915. [CrossRef]

63. Grueneberg, J.; Engelen, A.H.; Costa, R.; Wichard, T. Macroalgal morphogenesis induced by waterborne compounds and bacteria in coastal seawater. PLoS ONE 2016, 11, e0146307. [CrossRef]

64. Poretsky, R.S.; Sun, S.; Mou, X.; Moran, M.A. Transporter genes expressed by coastal bacterioplankton in response to dissolved organic carbon. Environ. Microbiol. 2010, 12, 616-627. [CrossRef] [PubMed]

65. Longford, S.R.; Tujula, N.A.; Crocetti, G.R.; Holmes, A.J.; Holmström, C.; Kjelleberg, S.; Steinberg, P.D.; Taylor, M.W. Comparisons of diversity of bacterial communities associated with three sessile marine eukaryotes. Aquat. Microb. Ecol. 2007, 48, 217-229. [CrossRef] 
66. Liu, M.; Xiao, T.; Sun, J.; Wei, H.; Wu, Y.; Zhao, Y.; Zhang, W. Bacterial community structures associated with a natural spring phytoplankton bloom in the Yellow Sea, China. Deep Sea Res. Part II Top. Stud. Oceanogr. 2013, 97, 85-92. [CrossRef]

67. Bik, E.M.; Costello, E.K.; Switzer, A.D.; Callahan, B.J.; Holmes, S.P.; Wells, R.S.; Carlin, K.P.; Jensen, E.D.; Venn-Watson, S.; Relman, D.A. Marine mammals harbor unique microbiotas shaped by and yet distinct from the sea. Nat. Commun. 2016, 7, 10516. [CrossRef] [PubMed]

68. Han, Y.; Li, L.; Liu, J.; Zhang, M. Microbial structure and chemical components of aerosols caused by rotating brushes in a wastewater treatment plant. Environ. Sci. Pollut. Res. Int. 2012, 19, 4097-4108. [CrossRef]

69. Lee, I.; Jang, G.I.; Cho, Y.; Yoon, S.J.; Pham, H.M.; Nguyen, A.V.; Lee, Y.M.; Park, H.; Rhee, T.S.; Kim, S.H.; et al. Sandaracinobacter neustonicus sp. nov., isolated from the sea surface microlayer in the Southwestern Pacific Ocean, and emended description of the genus Sandaracinobacter. Int. J. Syst. Evol. Microbiol. 2020, 70, 4698-4703. [CrossRef]

70. Wurl, O.; Miller, L.; Vagle, S. Production and fate of transparent exopolymer particles in the ocean. J. Geophys Res. Oceans 2011, 116, C00H13. [CrossRef]

71. Hunter, K. Processes affecting particulate trace metals in the sea surface microlayer. Mar. Chem. 1980, 9, 49-70. [CrossRef]

72. Alldredge, A.L.; Cohen, Y. Can microscale chemical patches persist in the sea? Microelectrode study of marine snow, fecal pellets. Science 1987, 235, 689-691. [CrossRef]

73. Ploug, H.; Kühl, M.; Buchholz-Cleven, B.; Jørgensen, B.B. Anoxic aggregates-An ephemeral phenomenon in the pelagic environment? Aquat. Microb. Ecol. 1997, 13, 285-294. [CrossRef]

74. Harold, E.; Schlichting, J.R. A preliminary study of the algae and protozoa in seafoam. Bot. Mar. 1971, 14, 24-28. [CrossRef]

75. Roveillo, Q.; Dervaux, J.; Wang, Y.; Rouyer, F.; Zanchi, D.; Seuront, L.; Elias, F. Trapping of swimming microalgae in foam. J. R. Soc. Interface 2020, 17, 20200077. [CrossRef] [PubMed]

76. Gong, J.; Qing, Y.; Guo, X.; Warren, A. “Candidatus Sonnebornia yantaiensis”, a member of candidate division OD1, as intracellular bacteria of the ciliated protist Paramecium bursaria (Ciliophora, Oligohymenophorea). Syst. Appl. Microbiol. 2014, 37, 35-41. [CrossRef] [PubMed]

77. Probst, A.J.; Elling, F.J.; Castelle, C.J.; Zhu, Q.; Elvert, M.; Birarda, G.; Holman, H.-Y.N.; Lane, K.R.; Ladd, B.; Ryan, M.C.; et al. Lipid analysis of $\mathrm{CO}_{2}$-rich subsurface aquifers suggests an autotrophy-based deep biosphere with lysolipids enriched in CPR bacteria. ISME J. 2020, 14, 1547-1560. [CrossRef] [PubMed]

78. Starr, E.P.; Shi, S.; Blazewicz, S.J.; Probst, A.J.; Herman, D.J.; Firestone, M.K.; Banfield, J.F. Stable isotope informed genome-resolved metagenomics reveals that Saccharibacteria utilize microbially-processed plant-derived carbon. Microbiome 2018, 6, 122. [CrossRef] [PubMed]

79. Bor, B.; Collins, A.J.; Murugkar, P.P.; Balasubramanian, S.; To, T.T.; Hendrickson, E.L.; Bedree, J.K.; Bidlack, F.B.; Johnston, C.D.; Shi, W.; et al. Insights obtained by culturing Saccharibacteria with their bacterial hosts. J. Dent. Res. 2020, 99, 685-694. [CrossRef] [PubMed]

80. Cross, K.L.; Campbell, J.H.; Balachandran, M.; Campbell, A.G.; Cooper, S.J.; Griffen, A.; Heaton, M.; Joshi, S.; Klingeman, D.; Leys, E.; et al. Targeted isolation and cultivation of uncultivated bacteria by reverse genomics. Nat. Biotechnol. 2019, 37, 1314-1321. [CrossRef]

81. Kindaichi, T.; Yamaoka, S.; Uehara, R.; Ozaki, N.; Ohashi, A.; Albertsen, M.; Nielsen, P.H.; Nielsen, J.L. Phylogenetic diversity and ecophysiology of Candidate phylum Saccharibacteria in activated sludge. FEMS Microbiol. Ecol. 2016, 92, fiw078. [CrossRef]

82. Bärlocher, F.; Gordon, J.; Ireland, R.J. Organic composition of seafoam and its digestion by Corophium volutator (Pallas). J. Exp. Mar. Biol. Ecol. 1988, 115, 179-186. [CrossRef]

83. Wegner, C.; Hamburger, M. Occurrence of stable foam in the upper Rhine River caused by plant-derived surfactants. Environ. Sci. Technol. 2002, 36, 3250-3256. [CrossRef]

84. Velimirov, B. Sugar and lipid components in sea foam near kelp beds. Mar. Ecol. 1982, 3, 97-107. [CrossRef]

85. Ram, A.S.P.; Mari, X.; Brune, J.; Torreton, J.P.; Chu, V.T.; Raimbault, P.; Niggemann, J.; Sime-Ngando, T. Bacterial-viral interactions in the sea surface microlayer of a black carbon-dominated tropical coastal ecosystem (Halong Bay, Vietnam). Elementa Sci. Anthrop. 2018, 6, 13. [CrossRef]

86. Jeffrey, W.H.; Kase, J.P.; Wilhelm, S.W. UV Radiation effects on heterotrophic bacterioplankton and viruses in marine ecosystems. In The effects of UV Radiation in the Marine Environment; Cambridge University Press: Cambridge, UK, 2000; Volume 10, pp. 206-236. [CrossRef] 
87. Agogué, H.; Joux, F.; Obernosterer, I.; Lebaron, P. Resistance of marine bacterioneuston to solar radiation. Appl. Environ. Microbiol. 2005, 71, 5282-5289. [CrossRef] [PubMed]

88. Tranvik, L.; Olofsson, H.; Bertilsson, S. Photochemical effects on bacterial degradation of dissolved organic matter in lake water. In Proceedings of the Microbial Biosystems: New Frontiers, the 8th International Symposium on Microbial Ecology, Halifax, NS, Canada, 9-14 August 1999.

89. Bor, B.; McLean, J.S.; Foster, K.R.; Cen, L.; To, T.T.; Serrato-Guillen, A.; Dewhirst, F.E.; Shi, W.; He, X. Rapid evolution of decreased host susceptibility drives a stable relationship between ultrasmall parasite TM7x and its bacterial host. Proc. Natl. Acad. Sci. USA 2018, 115, 12277-12282. [CrossRef] [PubMed]

90. Utter, D.R.; He, X.; Cavanaugh, C.M.; McLean, J.S.; Bor, B. The saccharibacterium TM7x elicits differential responses across its host range. ISME J. 2020, 14, 3054-3067. [CrossRef] [PubMed]

91. Eisenreich, S.J.; Elzerman, A.W.; Armstrong, D.E. Enrichment of micronutrients, heavy metals, and chlorinated hydrocarbons in wind-generated lake foam. Environ. Sci. Technol. 1978, 12, 413-417. [CrossRef]

92. Kuznetsova, M.; Lee, C. Dissolved free and combined amino acids in nearshore seawater, sea surface microlayers and foams: Influence of extracellular hydrolysis. Aquat. Sci. 2002, 64, 252-268. [CrossRef]

93. Craig, D.; Ireland, R.J.; Bärlocher, F. Seasonal variation in the organic composition of seafoam. J. Exp. Mar. Biol. Ecol. 1989, 130, 71-80. [CrossRef]

94. Wurl, O.; Obbard, J.P. A review of pollutants in the sea-surface microlayer (SML): A unique habitat for marine organisms. Mar. Pollut. Bull. 2004, 48, 1016-1030. [CrossRef]

95. Santos, A.L.; Lopes, S.; Baptista, I.; Henriques, I.; Gomes, N.C.; Almeida, A.; Correia, A.; Cunha, A. Diversity in UV sensitivity and recovery potential among bacterioneuston and bacterioplankton isolates. Lett. Appl. Microbiol. 2011, 52, 360-366. [CrossRef]

96. Robinson, T.B.; Wurl, O.; Bahlmann, E.; Jürgens, K.; Stolle, C. Rising bubbles enhance the gelatinous nature of the air-sea interface. Limnol. Oceanogr. 2019, 64, 2358-2372. [CrossRef]

97. Hardy, J.T. The sea surface microlayer: Biology, chemistry and anthropogenic enrichment. Prog. Oceanogr. 1982, 11, 307-328. [CrossRef]

98. Aller, J.Y.; Kuznetsova, M.R.; Jahns, C.J.; Kemp, P.F. The sea surface microlayer as a source of viral and bacterial enrichment in marine aerosols. J. Aerosol. Sci. 2005, 36, 801-812. [CrossRef]

99. Rahlff, J. The virioneuston: A review on viral-bacterial associations at air-water interfaces. Viruses 2019, 11, 191. [CrossRef] [PubMed]

100. Michaud, J.M.; Thompson, L.R.; Kaul, D.; Espinoza, J.L.; Richter, A.R.; Xu, Z.Z.; Lee, C.; Pham, K.M.; Beall, C.M.; Malfatti, F.; et al. Taxon-specific aerosolization of bacteria and viruses in an experimental ocean-atmosphere mesocosm. Nat. Commun. 2018, 9, 2017. [CrossRef] [PubMed]

101. Fahlgren, C.; Hagstrom, A.; Nilsson, D.; Zweifel, U.L. Annual variations in the diversity, viability, and origin of airborne bacteria. Appl. Environ. Microbiol. 2010, 76, 3015-3025. [CrossRef] [PubMed]

102. Rastelli, E.; Corinaldesi, C.; Dell'Anno, A.; Lo Martire, M.; Greco, S.; Cristina Facchini, M.; Rinaldi, M.; O'Dowd, C.; Ceburnis, D.; Danovaro, R. Transfer of labile organic matter and microbes from the ocean surface to the marine aerosol: An experimental approach. Sci. Rep. 2017, 7, 11475. [CrossRef]

103. Fleck, R.; Gill, R.L.; Pettit, T.; Irga, P.J.; Williams, N.L.R.; Seymour, J.R.; Torpy, F.R. Characterisation of fungal and bacterial dynamics in an active green wall used for indoor air pollutant removal. Build. Environ. 2020, 179, 106987. [CrossRef]

104. Mortazavi, R.; Attiya, S.; Ariya, P.A. Arctic microbial and next-generation sequencing approach for bacteria in snow and frost flowers: Selected identification, abundance and freezing nucleation. Atmos. Chem. Phys. 2015, 15, 6183-6204. [CrossRef]

105. Møller, A.K.; Søborg, D.A.; Abu Al-Soud, W.; Sørensen, S.J.; Kroer, N. Bacterial community structure in High-Arctic snow and freshwater as revealed by pyrosequencing of 16S rRNA genes and cultivation. Polar Res. 2013, 32, 17390. [CrossRef]

106. Cuthbertson, L.; Amores-Arrocha, H.; Malard, L.A.; Els, N.; Sattler, B.; Pearce, D.A. Characterisation of Arctic bacterial communities in the air above Svalbard. Biology 2017, 6, 29. [CrossRef] [PubMed] 
107. Allen, J.R.L. A beach structure due to wind-driven foam. J. Sediment. Res. 1967, 37, 691-692. [CrossRef]

108. Jenkinson, I.R.; Laurent, S.; Ding, H.; Elias, F. Biological modification of mechanical properties of the sea surface microlayer, influencing waves, ripples, foam and air-sea fluxes. Elem. Sci. Anth. 2018, 6. [CrossRef]

Publisher's Note: MDPI stays neutral with regard to jurisdictional claims in published maps and institutional affiliations.

(C) 2020 by the authors. Licensee MDPI, Basel, Switzerland. This article is an open access article distributed under the terms and conditions of the Creative Commons Attribution (CC BY) license (http://creativecommons.org/licenses/by/4.0/). 